\title{
Does Reflective Practice ANd Personalised FeEdBack FOSTER LEARNING?
}

\author{
Mohamad Azhari Abu Bakar* \\ Psychology Programme, Faculty of Cognitive Sciences and Human Development \\ Universiti Malaysia Sarawak, Kota Samarahan \\ Malaysia \\ abmazhari@unimas.my
}

\section{Kartini Abd Ghani}

Psychology Programme, Faculty of Cognitive Sciences and Human Development Universiti Malaysia Sarawak, Kota Samarahan Malaysia gkartini@unimas.my

\section{Ida Juliana Hutasuhut}

Psychology Programme, Faculty of Cognitive Sciences and Human Development Universiti Malaysia Sarawak, Kota Samarahan Malaysia

hijuliana@unimas.my

\section{Jamayah Saili}

Psychology Programme, Faculty of Cognitive Sciences and Human Development Universiti Malaysia Sarawak, Kota Samarahan Malaysia

sjamayah@unimas.my

*Corresponding author's Email: abmazhari@ unimas.my

Peer-review under responsibility of 5th ${ }^{d}$ Asia International Conference 2019 Scientific Committee http://connectingasia.org/scientific-committee/ (C) 2019 Published by Readers Insight Publisher, lat 306 Savoy Residencia, Block 3 F11/1,44000 Islamabad. Pakistan,

editor@readersinsight.net

This is an open access article under the CC BY-NC-ND license (http://creativecommons.org/licenses/by-nc-nd/4.0/). 


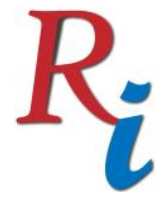

Asia Proceedings of Social Sciences

(APSS)

www.readersinsight.net/APSS

\section{Rese a r ch H igh I ight s}

Reflective practice is proven as an evidence-based approach in education science. It guides learners to actively engage in critical evaluation of their thoughts, actions, and experience to construct a meaningful framework of understanding. Implementation of reflective practice in learning nurtures students' self-directed learning to be accountable for their learning journey (Knowles, Gilbourne, Borrie, \& Nevill, 2001). Eventually, they can experience deep learning (Parry, Walsh, Larsen, \& Hogan, 2012), with the activation of active thinking (Louis \& Sutton, 1991) and working memory. The growth of reflective practice requires a high level of attentional control, and metacognition to produce a large spectrum of content knowledge with various mental languages (emotive, volitive, and cognitive). However, the contents of reflective practice have to be guided with personalised feedbacks by the instructors to foster the quality of reflective practice. The instructor has to be catered with the structured rubric of evaluation to provide professional feedback to the student's reflective writing. Therefore, in this study, each reflective writing produced by the student was evaluated based on five categories of the reflective style produced by Bruno \& Gilardi (2014).

\section{Research Objectives}

The main objective of this study is to explore the impact of reflective practice implementation in teaching and learning of undergraduate psychology students. Previous research highlighted that reflective practice is common in the field of counselling, teacher education, sciences, medicine and health sciences (Neville, 2018). Being psychology students, they need to understand how to apply the knowledge they have learned to the real world. This approach helps to develop and foster a critical style of thinking and learning. Therefore, the specific goal of this research is to investigate the various levels of reflective practices produced by students, and whether with personalised feedback and assistance from instructors will eventually enhance and foster learning. The significance of this study is to promote the use of reflective practices in student's teaching and learning. Findings from this research can add evidence that self-directed reflective practice empowers student's cognitive processing and provide an opportunity for them to improve continuously. 


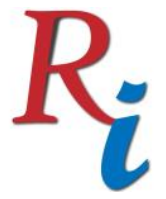

Asia Proceedings of Social Sciences

(APSS)

www.readersinsight.net/APSS

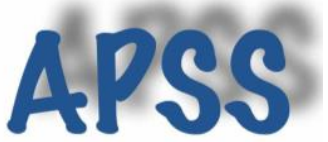

\section{Methodology}

A mixed-method design that includes qualitative research (content analysis) and quantitative research (overall performance according to each category of reflective practice, frequency of each category in every week, frequency of personalised feedback and measure of academic performance) were employed in this study. Twenty-five (25) first-year psychology (session 2018/2019) students in the Psychology and Individual Difference course gave their consent to participate in this project. Each week, every respondent was encouraged to write a reflective response after each content knowledge was presented. A total of ten (10) weeks were dedicated to this research purpose. The instructor provided personalised feedback to each reflective entry which contains constructive comments and suggestions so that students can improve the way they think and reflect. Each reflection was given a category based on reflective practice styles (Bruno \& Gilardi, 2014). The measure of academic performance was based on the final grades the students achieve at the end of the course. Data from the reflective documents, the five categories of reflective style, the personalised feedback, final grades of the students were all documented and collected to be further analysed.

\section{Results}

Based on the frequency of the five levels of reflective styles, the data indicate variations in the categories of reflective styles. About half of the reflective writings were categorised as having Category 3 (interpretative reflective practice) as well as in the Category 4 (critical reflective practice); while the rest centred in Category 2 (relational reflective practice), Category 1(relational reflective practice), and the small percentage in Category 0 (non reflective practice). The performance of reflective practice in Category 0 and Category 1 was shown to decrease while the reflective practice in Category 3 and 4 increase in week 10 . Results also show an indication of the number of frequency of reflective practice to be contributing to higher grades. Personalised feedback was also analysed and a positive relationship was found between the number of personalised feedback received by the students and the quality of reflective writings.

\section{Findings}

Copyright $\odot 2019$ Authors. This is an open access article distributed under the Creative Commons Attribution License, which permits unrestricted use, distribution, and reproduction in any medium, provided the original work is properly cited. 


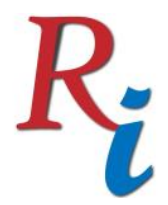

\section{Asia Proceedings of Social Sciences \\ (APSS) \\ www.readersinsight.net/APSS}

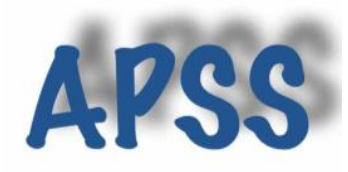

Overall, findings from this research provide additional scientific evidence (Dunn, Saville, Baker, \& Marek, 2013) that shows the reflective practice is a concrete approach in instilling metacognition, active thinking and meaningful learning in our Psychology students. However, personalised feedbacks on students' reflection and positive encouragement are also needed for the approach to be more effective. Creating a supportive learning environment can assist in building the habits of students to always think of their learning and constantly linking and constructing meaning from those experiences.

\section{Acknowledgment}

This study was conducted under the Scholarship of Teaching and Learning (SoTL Grant) Universiti Malaysia Sarawak (UNIMAS) with the project number (SoTL/FSKPM/2018(1)/010)

\section{References}

Bruno, A. \& Gilardi, S. (2014). Assessing reflective competence through students' journals. Reflexivity in higher education, 179-190.

Dunn, D. S., Saville, B. K., Baker, S. C., \& Marek, P. (2013). Evidence-based teaching: Tools and techniques that promote learning in the psychology classroom. Australian Journal of Psychology, 65(1), 5-13.

Knowles, Z., Gilbourne, D., Borrie, A., \& Nevill, A. (2001). Developing the reflective sports coach: A study exploring the processes of reflective practice within a higher education coaching program. Reflective practice, 2(2), 185-207.

Louis, M. R., \& Sutton, R. I. (1991). Switching cognitive gears: From habits of mind to active thinking. Human Relations, 44(1), 55-76.

Neville, P. (2018). Introducing dental students to reflective practice: a dental educator's reflections. Reflective Practice, 19(2), 278-290.

Parry, D., Walsh, C., Larsen, C. \& Hogan, J. (2012) Reflective Practice: a place in enhancing learning in the undergraduate bioscience teaching laboratory?, Bioscience Education, 19:1, 110. 